\title{
La ciclooxigenasa-2 (COX-2) y el factor de crecimiento epidérmico (EFG) en lesiones epiteliales orales premalignas
}

\author{
Cyclooxygenase-2 (COX-2) and epidermal growth factor (EGF) in oral \\ premalignant epithelial lesions
}

\author{
S. Díaz Prado1, A. Gallego Guadalupe2, J.L. López-Cedrún³, J. Ferreras Granado4, L. Antón Aparicio1,5
}

Resumen: Las lesiones premalignas orales incluyen eritroplasias (manchas rojas) y leucoplasias (manchas blancas), las cuales se desarrollan a lo largo de superficies epiteliales. Estas lesiones son considerados marcadores en la "carcinogénesis de campo" ya que pacientes con lesiones premalignas orales pueden desarrollar carcinoma de células escamosas (CCS) en el sitio de las lesiones, así como en otros lugares de tracto aerodigestivo superior. Se está haciendo un gran esfuerzo para identificar nuevos biomarcadores SEBs (surrogate endpoint biomarkers) para el carcinoma de células escamosas de cabeza y cueIlo. Los SEBs candidatos para el carcinoma de células escamosas invasivo en el trato aerodigestivo superior deben ser detectables con los cambios moleculares celulares y tisulares que tienen lugar durante la formación del tumor. Entre los diferentes marcadores que se han propuesto hasta la actualidad, la ciclooxigenasa-2 (COX-2) y el receptor del factor de crecimiento epidérmico (EGFR) parecen ser los más prometedores. COX-2 se sobre expresa durante el proceso tumoral, desde hiperplasia temprana a enfermedad metastásica. EGFR también está anormalmente activado en tumores epiteliales, pues las células de casi todas estas neoplasias expresan altos niveles de este receptor, una característica asociada con un peor pronóstico clínico. En este sentido el tracto aerodigestivo superior proporciona un sistema o modelo único para el estudio de CCS y para la investigación de nuevos candidatos SEBs.

Palabras clave: Factor de crecimiento epidérmico; Ciclooxigenasa-2; Carcinoma de células escamosas de cabeza y cuello; Lesión premaligna oral; Biomarcador; Carcinogénesis de campo.

Recibido: 08.10 .08

Aceptado: 02.03.09

\footnotetext{
1 Dra. en Biología.Departamento de Medicina. Universidad de La Coruña. La Coruña. INIBIC.

2 Unidad de Investigación. Estudiante de Biología.

3 Servicio Cirugía Oral y Maxilofacial. Jefe de Servicio, Dr. en Medicina.

4 Servicio Cirugía Oral y Maxilofacial. Médico Especialista, Licenciado en Medicina.

5 Departamento de Medicina. Universidad de La Coruña. La Coruña, España. Servicio

Oncología Médica. Jefe de Servicio, Dr. en Medicina.

C.H.U. A Coruña. La Coruña, España.
}

\section{Correspondencia:}

L.M. Antón Aparicio

Servicio Oncología Médica

C.H.U. A Coruña. Hospital Materno Infantil Teresa Herrera

$\mathrm{C} /$ As Xubias $\mathrm{S} / \mathrm{N}$

15006 A Coruña. España

E-mail: lantapa@canalejo.org
Abstract: Oral premalignant lesions include leukoplakia (white patch) and erythroplakia (red patch), which develop on epithelial surfaces. These lesions are markers for field cancerization because patients with oral premalignancy can develop squamous cell carcinoma at the site of the lesion(s) and at other sites in the upper aerodigestive tract. An effort is being made to identify surrogate endpoint biomarkers (SEBS) for head and neck squamous cell carcinoma (HNSCC). Candidate SEBs for invasive squamous cell carcinoma (SCC) of the upper aerodigestive tract are detectable molecular, cellular, and tissue changes that take place during tumorigenesis. Among the markers that have been proposed to date, cyclooxygenase-2 (COX-2) and the epidermal growth factor receptor (EGFR) seem to be the most promising. COX-2 is overexpressed during tumor transformation from early hyperplasia to metastasic disease. EGFR is also abnormally activated in epithelial tumors, since cells of almost all these kinds of neoplasm express high levels of this receptor, a characteristic associated with poor clinical outcome. The upper aerodigestive tract provides a unique model for studying the development of squamous cell carcinoma and for investigating candidate SEBS.

Key words: Epidermal growth factor; Cyclooxygenase-2; Head and neck squamous cell carcinoma; Oral premalignant lesion; Biomarker; Field cancerization. 


\section{Introducción}

La carcinogénesis en el tracto aerodigestivo superior es un proceso que consta de múltiples pasos. Histológicamente este proceso consiste en la transición, a lo largo del tiempo, desde epitelio normal, hiperplasia, displasia hasta CCS. Esta transición histológica consta de múltiples cambios moleculares y celulares, incluyendo cambios en la expresión de genes que codifican para receptores/factores de crecimiento. Durante las últimas décadas se ha empleado el término "carcinogénesis de campo" para describir las anomalías histológicas (Hiperplasia, Displasia y CCS in situ) detectadas en la mayoría de los epitelios normales adyacentes al CCS extirpado. Entre los diferentes SEBs, la ciclooxigenasa-2 (COX-2) y el receptor para el factor de crecimiento epidérmico (EGFR) están interrelacionados. Existen evidencias indicadoras que la sobre expresión de COX-2 y EGFR constituyen un evento temprano en la carcinogénesis epitelial, postulándose que el aumento en los niveles de COX2 y EGFR en lesiones premalignas constituyen un mecanismo de "carcinogénesis de campo". Si estos biomarcadores (COX-2 y EGFR) están sobre expresados en el carcinoma de células escamosas (CCS), puede inducirse que la carcinogénesis, crecimiento y supervivencia de un subconjunto de lesiones premalignas orales pueden depender de una interferencia de los mismos actores en diferentes roles y escenarios (Tabla 1).

\section{Lesiones premalignas de la mucosa oral}

\section{Eritroplasia}

La eritroplasia es definida como una mancha roja aterciopelada que no puede ser clínica o patológicamente atribuida a ninguna enfermedad específica. Algunos investigadores consideran la eritroplasia como la primera señal de carcinoma de células escamosas asintomático de la cavidad oral. Las lesiones eritroplásicas y leucoplásicas pueden ser consideradas como un continuo, ya que ambas pueden transformarse en lesiones malignas. Una presentación esquemática de una eritroplasia/leucoplasia define los descubrimientos microscópicos que pueden ser vistos en asociación con cambios neoplásicos potenciales de la membrana mucosa oral a medida que mosas (CCS)

Tabla 1. Patrones de expresión de COX-2 y EGFR en carcinoma de células esca-

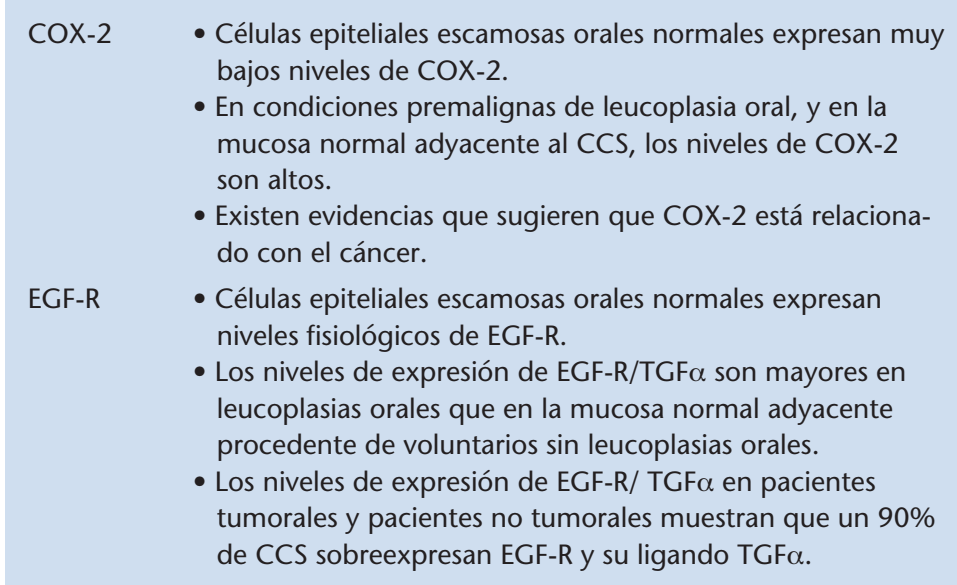

Table 1. Patterns of COX-2 and EGFR expression in squamous-cell carcinoma (SCC)

COX-2 levels.

In premalignant conditions of oral leukoplakia and in the high.

- Evidence exists suggesting that COX-2 is related to cancer.

levels of EGF-R.

leukoplakias oral than in the adjacent normal mucosa from

volunteers without oral leukoplakias.

- The levels of expression of EGF-R/TGF- $\alpha$ in patients with and without tumor show that $90 \%$ of SCCS overexpress EGF-R and its ligand TGF- $\alpha$.

\section{Introduction}

Carcinogenesis in the upper aerodigestive tract is a process consisting of several steps. Histologically, the process is a transition over time from normal epithelium to hyperplasia, dysplasia, and squamouscell carcinoma (SCC). This histologic transition involves a series of molecular and cellular changes, including changes in the expression of genes that encode growth receptors and growth factors. In recent decades the term "field cancerization" has been used to describe the histologic anomalies (hyperplasia, dysplasia, and SCC in situ) detected in most of the normal epithelia adjacent to a resected SCC. Among the different surrogate endpoint biomarkers (SEB), cyclooxygenase-2 (COX-2) and epidermal growth factor receptor (EGFR) are interrelated. Evidence indicates that COX-2 and EGFR overexpression is an early event in epithelial carcinogenesis. It is postulated that the increase in COX-2 and EGFR levels in premalignant lesions constitutes a mechanism of "field cancerization". If these biomarkers (COX-2 and EGFR) are overexpressed in squamous-cell carcinoma (SCC), it can be deduced that the genesis, growth, and survival of a subgroup of oral premalignant lesions could depend on the intervention of the same actors in different roles and scenarios (Table 1).

\section{Premalignant lesions of the oral mucosa}

\section{Erythroplakia}

Erythroplakia is defined as a velvety-textured red spot that cannot be attributed clinically or pathologically to any specific disease. Some investigators consider erythroplakia as the first sign of asymptomatic SCC of the oral cavity. Erythroplakic and leukoplakic lesions can be viewed as a con- 
el tejido progresa desde hiperqueratosis benigna a través de varias etapas de eritroleucoplasia. Las lesiones eritroplásicas y leucoplásicas a veces son englobadas dentro de la misma categoría como leucoplasia manchada o eritroleucoplasia manchada, ya que en muchos casos no es posible diferenciar ambos tipos de lesiones.

\section{Leucoplasia}

La leucoplasia se define como una mancha o placa blanca en la mucosa oral. La leucoplasia ha sido clasificada en varios subtipos diferentes y aproximadamente un $6 \%$ de todas las leucoplasias orales se convierten en malignas. En una evaluación de pacientes con leucoplasias sobre los que se les realizó un seguimiento de 3 años, se observó que un $31 \%$ de las lesiones desaparecieron, un $25 \%$ permanecieron sin cambios y un 30\% mejoraron.

\section{Displasia epitelial oral}

La displasia epitelial es una condición premaligna caracterizada clínicamente por una alteración en el epitelio que puede provocar que la mucosa oral se vuelva roja, blanca o de otro color. Microscópicamente, la displasia se ha clasificado como leve, moderada o severa. La displasia epitelial puede llegar a ser progresiva en un cierto plazo, aunque en algunos casos, las formas suaves de displasia pueden ser reversibles.

\section{Carcinogénesis de la mucosa oral}

El desarrollo de CCS es un proceso que consta de múltiples pasos que implican cambios relacionados con genes específicos, eventos epigenéticos y transducción de señales dentro de la célula (Fig. 1). Las alteraciones genéticas que están presentes muy tempranamente en el curso de la carcinogénesis son mutaciones o deleciones de $3 p$ y $9 \mathrm{p}$. La activación de la telomerasa también ocurre tempranamente en la carcinogénesis. ${ }^{1}$ Las mutaciones o deleciones de $17 p$ (implicando el gen supresor de tumores $p 53$ ), $13 q$ y $18 q$ generalmente tienen lugar más tarde en el proceso de carcinogénesis. Un evento epigenético importante en la progresión del cáncer es el silenciamiento de regiones promotoras de genes a través de la hipermetilación, la cual se ha mostrado que afecta al gen supresor de tumor p16, DAP-quinasa y E-cadherina. ${ }^{2,3}$ También el gen que codifica para el receptor del ácido retinoico beta (RAR-beta) está silenciado por metilación de su promotor. ${ }^{4} \mathrm{El}$ humo del tabaco, que contiene agentes que pueden actuar como mutágenos, activa el receptor del factor de crecimiento epidérmico. A su vez esta activación del EGFR provoca un aumento de la producción de prostaglandinas, incluida la $\mathrm{PGE}_{2}$, pudiendo esta actuar como retroalimentador positivo, incrementando la transducción de la señal EGFR. ${ }^{5}$ La ciclina-D1 está
Leukoplakia

Leukoplakia is defined as a white spot or plaque on the oral mucosa. Leukoplakia has been classified into several different subtypes and approximately $6 \%$ of all oral leukoplakias become malignant. In an evaluation of patients with leukoplakia subjected to a 3-year follow-up, $31 \%$ of the lesions disappeared, $25 \%$ remained unchanged, and 30\% improved.

\section{Oral epithelial dysplasia}

Epithelial dysplasia is a premalignant condition characterized clinically by an alteration in the epithelium that can make the oral mucosa turn red, white, or another color. Microscopically, dysplasia has been classified as mild, moderate, or severe. Epithelial dysplasia can develop a progressive course over a certain period, although smooth forms of dysplasia can be reversible in some cases.

\section{Carcinogenesis of the oral mucosa}

The development of SCC is a process consisting of a series of steps that involve changes related to specific genes, epigenetic events, and signal transduction in the cell (Fig. 1). The genetic alterations present very early in the course of carcinogenesis are mutations or deletions of $3 p$ and $9 p$. Telomerase activation also occurs early in carcinogenesis. ${ }^{1}$ Mutations or deletions of $17 p$ (involving the p53 tumor suppressor gene), 13q, and 18q generally occur later in carcinogenesis. An important epigenetic event in the progression of cancer is the silencing of gene promoter regions by hypermethylation, which has been shown to affect the p16 gene suppressor gene, DAP-kinase, and E-cadherin.2,3 The gene that encodes the beta retinoic acid receptor (RAR-beta) 
generalmente sobreexpresada en cáncer de cabeza y cuello y la activación del EGF es responsable de la alta actividad de la ciclina-D1.6

\section{Ciclooxigenasa (COX)}

La COX es una enzima que limita la tasa de producción de prostaglandinas (PGs) y tromboxanos (TxB) a partir de ácido araquidónico libre. El precursor de PGs es el ácido araquidónico, un ácido graso poliinsaturado de 20 carbonos. El primer paso en la síntesis de PGs es la hidrólisis de fosfolípidos para producir araquidonato libre, una reacción catalizada por la fosfolipasa $A_{2}$. El oxígeno molecular es añadido al ácido araquidónico en una reacción catalizada por la actividad ciclooxigenasa de COX. Esta reacción produce un producto inestable, $\mathrm{PGG}_{2}$, que es convertido rápidamente a $\mathrm{PGH}_{2}$ por la actividad peroxidasa de COX (Fig. 2). $\mathrm{PGH}_{2}$ es el precursor común para todos los prostanoides (p.ej. prostaglandinas y tromboxanos), en reacciones catalizadas por sintasas específicas y diferentes. La enzima es bifuncional (Fig. 2) y se presenta como dos formas distintas: la enzima COX-1 que se expresa constitutivamente y está presente en la mayoría de las células y tejidos, y la isoenzima COX2 que es inducible y se expresa en respuesta a citoquinas, factores de crecimiento, oncogenes, estímulos y carcinógenos del tabaco. ${ }^{7}$ A pesar de que ambas poseen actividades enzimáticas similares, COX-1 y COX-2 poseen diferentes propiedades y distintos patrones de expresión (Tabla 2). La enzima COX-1 esta constitutivamente expresada con bajos niveles en la mayoría de los tejidos y sintetiza la prostaglandina pertinente para satisfacer las funciones fisiológicas normales. Por el contrario COX-2 no suele estar presente en la mayoría de las células, pero una fuerte regulación le permite ser rápidamente expresada en respuesta a señales relacionadas con el crecimiento. Este rápido incremento en la expresión resulta en un aumento en la síntesis de prostaglandinas asociadas con la inflamación y carcinogénesis, existiendo evidencias tangibles que COX-2 está sobre expresada en células estromales extra e intratumorales y así como en neoplásicas propias del tumor. Hay

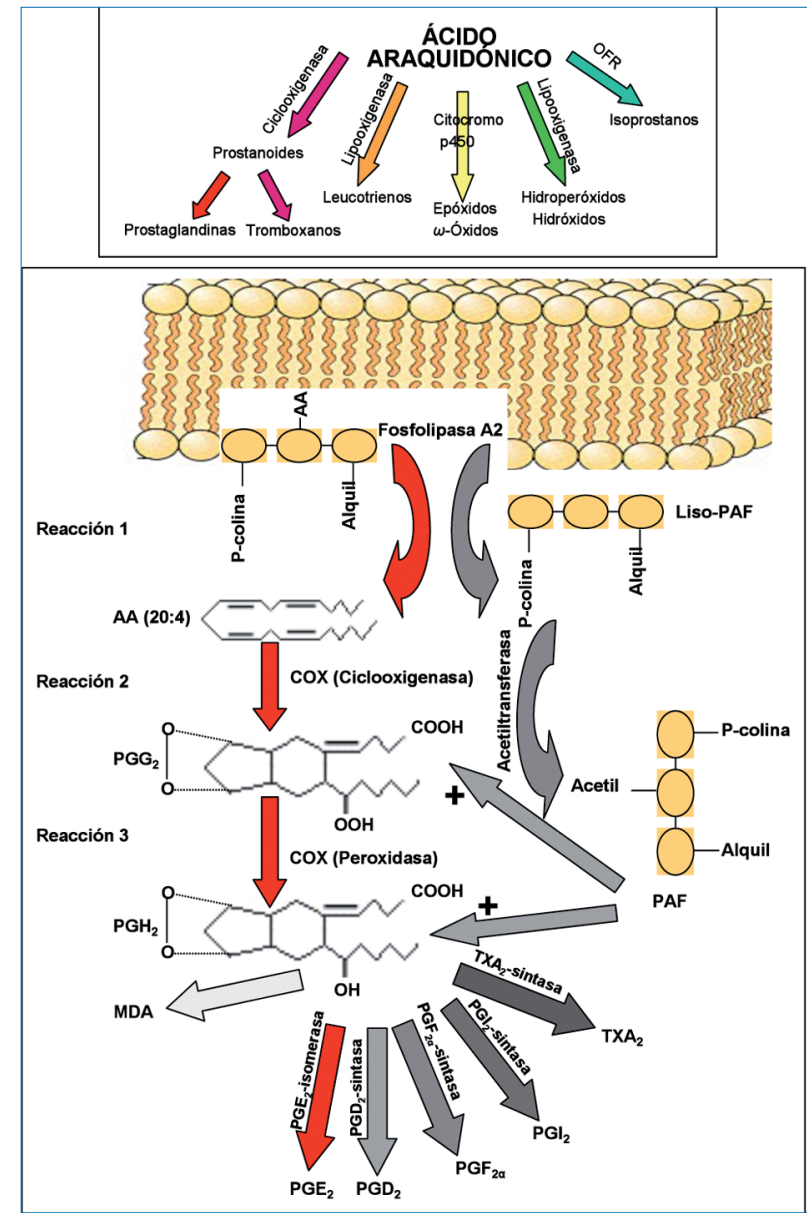

Figura 2. A. Mecanismos celulares de oxidación el ácido araquidónico (AA) y sus productos. El AA puede ser oxidado en las células por diferentes rutas dando lugar a diferentes grupos de compuestos. De entre todos ellos, los más conocidos y los que poseen actividades biológicas más importantes son los prostanoides, los productos de la ciclooxigenasa y los leucotrienos, un producto de la 5-lipooxigenasa. OFR (oxygen free radicals, radicales libres de oxígeno). B. Ruta enzimática de la ciclooxigenasa y sus productos finales. La síntesis de prostanoides requiere tres enzimas, fosfolipasa, que libera el AA de los fosfolípidos de la membrana, la ciclooxigenasa, que realiza dos actividades: ciclooxigenación y peroxidación, y finalmente las PG sintetasas o isomerasas que generan compuestos específicos. Los fosfolípidos pueden ser utilizados como precursores para la síntesis de PAF.

Figure 2. A. Cellular mechanisms and products of arachidonic acid $(A A)$ oxidation. AA can be oxidized in cells by different pathways that produce different groups of compounds. Of all of them, the best known pathways and the ones that have more important biological activities are the prostanoids, cyclooxygenase products, and the leukotrienes, a product of 5-lipooxygenase. OFR (oxygen free radicals). B. Enzymatic pathway of cyclooxygenase and its end products. Prostanoid synthesis requires three enzymes, phospholipase, which releases the $A A$ of phospholipids from the membrane, cyclooxygenase, which has two activities: cyclooxygenation and peroxidation, and finally PG synthases or isomerases, which generate specific compounds. Phospholipids can be used as precursors for PAF synthesis. is silenced by methylation of its promoter. ${ }^{4}$ Tobacco smoke, which contains agents that can act as mutagens, activates the epidermal growth factor receptor. EGFR activation, in turn, increases the production of prostaglandins, including $P G E_{2}$, which can exercise positive feedback and stimulate EGFR signal transduction. ${ }^{5}$ Cyclin-D1 generally is overexpressed in cancer of the head and neck and EGF activation is responsible for the high activity of cyclinD1.6

\section{Cyclooxygenase (COX)}

COX is an enzyme that limits the rate of production of prostaglandins (PGs) and thromboxanes ( $T \times B$ ) from free arachidonic acid. The precursor of $P G$ is arachidonic acid, a 20-carbon polyunsaturated fatty acid. The first step in PG synthesis is the hydrolysis of phospholipids to produce free arachidonate, a reaction catalyzed by phospholipase A2 Molecular oxygen is added to arachidonic acid in a reaction catalyzed by the cyclooxygenase activity of COX. This reaction produces an unstable product, $P G G_{2}$, that is rapidly converted into $\mathrm{PGH}_{2}$ by the peroxidase activity of $\mathrm{COX}$ (Fig. 2). $\mathrm{PGH}_{2}$ is the common precursor of all the prostanoids (e.g., prostaglandins and thromboxanes) in reactions catalyzed by different specific synthases. The enzyme is bifunctional (Fig. 2) and has two different forms: COX-1 enzyme, which is expressed constitutively and is present in most cells and tissues, and COX-2 isoenzyme, which is inducible and expressed in response to cytokines, growth factors, oncogenes, stimuli, and tobacco carcinogens. ${ }^{7}$ Although COX-1 
varios mecanismos que explican la sobre expresión de COX-2 en estos tipos celulares: la expresión de COX-2 está generalmente regulada a nivel transcripcional y post-transcripcional, aunque también puede ser regulada por la tasa de síntesis / degradación de la proteína; el promotor de COX2 humano contiene múltiples sitios de unión a factores transcripcionales, incluyendo el elemento de respuesta a cAMP y sitios de unión potenciales para Myb, para factores moleculares interleucina-6 (NF-IL6) y kB (NF$k b)$, y para factores Ets (Fig. 2). De todos estos sitios de unión, los más próximos al inicio de la transcripción son sensibles a varios estímulos. Puesto que COX-2 es una sintetasa de prostaglandinas, la consecuencia más obvia de la sobre expresión de COX-2 es el aumento en la producción de prostaglandinas. El incremento en la síntesis de PG puede contribuir a la carcinogénesis de varias formas, siendo destacable la estimulación del crecimiento celular: $\mathrm{PGE}_{2}$ y $\mathrm{PGF}_{2}$ estimulan la mitogénesis en sinergia con el factor de crecimiento epidérmico (EGF). COX-2, está sobre expresada en una variedad de condiciones premalignas y malignas, incluyendo leucoplasias orales y CCS. Niveles altos de COX-2 pueden contribuir a la carcinogénesis modulando el metabolismo xenobiótico, apoptosis, vigilancia inmune y angiogénesis. Se piensa que las PGs pueden ser importantes en la patogénesis del cáncer debido a efectos en la proliferación celular, angiogénesis, vigilancia inmune y apoptosis. ${ }^{8}$ Los niveles de COX-2 también están incrementados en la mucosa aparentemente normal adyacente a CCS. ${ }^{9}$ Existen múltiples evidencias que no sólo demuestran la sobre expresión de COX-2 en CCS sino que también sugieren la relación existente entre COX-2 y desarrollo tumoral.

\section{Mecanismos de COX-2 relacionados con la carcinogénesis}

COX-2 puede afectar a múltiples mecanismos importantes en la carcinogénesis. En general, COX-2 se sobre expresa durante el proceso tumoral, desde hiperplasia temprana a enfermedad metastásica (Fig. 3). En este sentido, se han detectado altos niveles de COX-2 en epitelio neoplásico, en células inflamatorias y vasculares intra y adyacente al tumor. Los metabolitos derivados de COX2 a partir de células inflamatorias de la infiltración contribuyen también al proceso carcinogénico. and COX-2 have similar enzymatic activities, they have different properties and different patterns of expression (Table 2). The COX-1 enzyme is expressed constitutively at low levels in most tissues, where it synthesizes the respective prostaglandin for normal physiologic functions. In contrast, COX-2 is not usually present in most cells, although strong regulation allows it to be rapidly expressed in response to growthrelated signals. This rapid increase in expression results in an increase in the synthesis of prostaglandins associated with inflammation and carcinogenesis. Tangible evidence exists that COX2 is overexpressed in extrastromal and intratumoral cells, as well as in the neoplastic cells of tumors. Several mechanisms explain $\mathrm{COX}-2$ overexpression in these cellular types: COX-2 expression generally is regulated at the transcriptional and post-transcriptional level, although it can also be regulated by the rate of synthesis or degradation of the protein. The human COX-2 promoter contains multiple binding sites for transcriptional factors, including the element of response to CAMP and potential binding sites for Myb, the molecular factors interleukin-6 (NF-IL6) and kB (NF-kb), and Ets factors (Fig. 2). Of all these binding sites, the sites closest to the initiation of transcription are sensitive to several stimuli. Since COX-2 is a prostaglandin synthase, the most obvious consequence of COX-2 overexpression is the increase in prostaglandin production. The increase in PG synthesis can contribute to carcinogenesis in various ways, notably by stimulating cellular growth: $P G E_{2}$ and $P G F_{2}$ stimulate mitogenesis in synergy with the epidermal growth factor (EGF). COX-2 is overexpressed in a variety of premalignant and malignant conditions, including oral leukoplakia and SCC. High COX-2 levels can contribute to carcinogenesis by modulating xenobiotic metabolism, apoptosis, immune monitoring, and angiogenesis. It is believed that PGs may be important in the pathogenesis of cancer due to their 


\section{Metabolismo xenobiótico}

La COX-2, enzima bifuncional, posee actividad peroxidasa y ciclooxigenasa; la actividad peroxidasa cataliza la conversión de procarcinógenos a carcinógenos. Las reacciones oxidativas son catalizadas principalmente por el citocromo P-450S. Tejidos como los del tracto aerodigestivo superior generalmente poseen bajas concentraciones de P-450S y, por lo tanto, cantidades significativas de xenobioticos pueden ser oxidados a mutágenos por la actividad peroxidasa de COX-2. Además de catalizar la síntesis de mutágenos, COX-2 puede también ser inducida por procarcinógenos: por ejemplo, el benzo [a] pireno $(B[a] P)$, un procarcinógeno del humo del tabaco, estimula la transcripción de COX2. En particular, la sobre expresión de COX2 puede condicionar un incremento en la producción de mutágenos: el malondialdehido (MDA) puede producirse por isomerización de $\mathrm{PGH} 2$ tanto por vía enzimática como por vía no enzimática. Además, existen otro tipo de carcinógenos adicionales que pueden formarse por oxidación de aminas aromáticas, aminas hete-

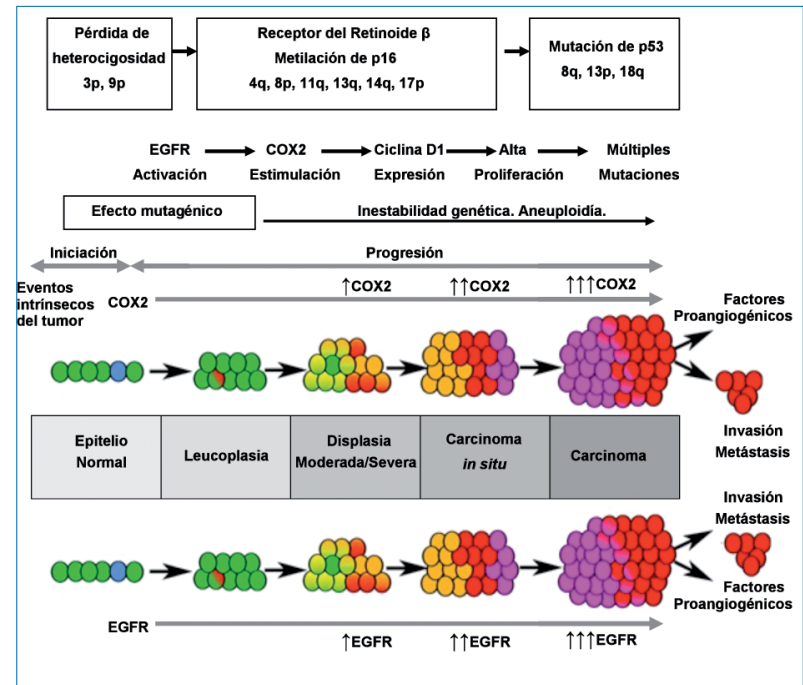

Figura 3. El desarrollo de lesiones preneoplásicas orales a carcinoma de células escamosas es un proceso de múltiples pasos que implica la activación de oncogenes y la pérdida de genes supresores de tumores como por ejemplo p53. Durante el desarrollo de este proceso, en carcinoma de cabeza y cuello, se produce una activación anormal de la expresión de EGFR/TGF $\alpha$.

Figure 3. The development from oral preneoplastic lesions to squamous-cell carcinoma is a process of multiple steps that involves the activation of oncogenes and the loss of tumor suppressor genes like, for example, p53. Abnormal activation of EGFR/TGF- $\alpha$ expression takes place during the development of this process in carcinoma of the head and neck. rocíclicas y derivados dihidrodiol de hidrocarburos policíclicos. De este modo, la sobreexpresión de COX-2 puede conducir a daños en el ADN, contribuyendo de este modo al proceso de carcinogénesis.

\section{Apoptosis}

Se ha comprobado que la apoptosis o muerte celular programada disminuye durante la carcinogénesis y la sobreexpresión de COX-2 en células epiteliales conduce a un descenso de la apoptosis. Este efecto ha sido atribuido, al menos en parte, a un aumento en los niveles de la proteína anti-apoptótica Bcl-2. Posiblemente, la sobreexpresión de COX-2 prolonga la supervivencia de células anormales favoreciendo la acumulación secuencial de cambios genéticos que aumentan el riesgo de carcinogénesis.

\section{Inflamación}

La inflamación crónica es un factor de riesgo reconocido en la carcinogénesis de los epitelios. La sobreexpresión de COX-2, mediada por citoquinas, contribuye al incremento en la síntesis de PGs en tejidos inflamados, proporcionando la base para una relación causa efecto entre la inflamación crónica y la carcinogénesis por medio de una sobreexpresión de COX-2.

\section{Angiogénesis}

Cualquier aumento significativo en la masa tumoral debe ser precedido por un incremento en el suministro vascular con el fin de poder aportar los nutrientes y oxígeno al tumor. Recientemente, se ha encontrado que los niveles de COX-2 están correlacionados con la expresión de VEGF y la vascularización del tumor en CCS.10 effects on cell proliferation, angiogenesis, immune monitoring, and apoptosis. ${ }^{8} \mathrm{COX}$ 2 levels also are increased in the apparently normal mucosa adjacent to SCC. ${ }^{9}$ Evidence exists that not only demonstrates COX-2 overexpression in SCC, but also suggests the relation existing between COX-2 and tumor development.

Carcinogenesis-related COX-2 mechanisms COX-2 can affect a number of important mechanisms in carcinogenesis. Generally speaking, COX-2 is overexpressed during the tumor process from early hyperplasia to metastatic disease (Fig. 3). In this sense, high COX-2 levels have been detected in neoplastic epithelium, inflammatory cells, and vascular cells within and adjacent to tumors. The COX-2 metabolites derived from the inflammatory cells of the infiltrate also contribute to carcinogenesis.

\section{Xenobiotic metabolism}

COX-2, a bifunctional enzyme, has peroxidase and cyclooxygenase activity; its peroxidase activity catalyzes the conversion of procarcinogen into carcinogen. Oxidative reactions are catalyzed mainly by the P-450S cytochrome. Tissues like those of the upper aerodigestive tract generally have low concentrations of P-450S. Consequently, significant amounts of xenobiotics can be oxidized to mutagens through the peroxidase activity of COX-2. In addition to catalyzing mutagen synthesis, COX-2 can also be induced by procarcinogens. For example, benzo $[a]$ pyrene $(B[a] P)$, a procarcinogen of tobacco smoke, stimulates COX-2 transcription. COX-2 overexpression, in particular, can condition an increase in mutagen production: malondialdehyde (MDA) can be produced by $\mathrm{PGH}_{2}$ isomerization via enzymatic and nonenzymatic pathways. In addition, other types of carcinogens can be formed by the oxidation of aromatic amines, heterocyclic amines, and dihydrodiol derivatives of polycyclic hydrocarbons. Through these mechanisms, COX-2 overexpression can lead to DNA damage, thus contributing to carcinogenesis.

\section{Apoptosis}

It has been shown that apoptosis, or programmed cell death, diminishes during carcinogenesis and that COX-2 


\section{Movilidad celular y adhesión}

La invasividad promovida por COX-2 está mediada por CD44, un receptor de superficie celular para el hialuronato. La sobreexpresión de COX-2 causa la invasividad celular y también incrementó la expresión de CD44. Los cambios bioquímicos asociados con esta dinámica celular tumoral incluyen un aumento de la expresión y alteración de la metaloproteinasa-2 y disminución de la expresión de la E-cadherina.

\section{Receptor del factor de crecimiento epidermico (EGFR)}

El receptor del EGF fue el primer receptor identificado de una familia de receptores conocidos como receptores ErbB; esta familia consta de los siguientes receptores relacionados: EGFR (ErbB1/EGFR/HER1), ErbB2 (HER2/neu), Erb3 (HER3) y ErbB4 (HER4). Bajo condiciones fisiológicas, una variedad de ligandos de la familia EGFR inducen la formación de complejos homo o heterodiméricos entre los cuatros tipos de receptores ErbB, los cuales mantienen la diversificación y ampliación de la señal. ${ }^{11}$ En las células tumorales estos receptores pueden ser activados por mecanismos adicionales y la sobreexpresión del receptor en el tumor puede conducir a la dimerización del receptor independiente del ligando. En algunos tumores las formas mutantes del EGFR, que acontecen a partir de cambios génicos, provocan un descenso de la expresión constitutiva del receptor dependiente del ligando. Estos fenómenos indican que las células tumorales pueden tener mecanismos de activación del EGFR adicionales aparte de la sobreexpresión del receptor, mutaciones y producción del ligando autocrino.

\section{Estructura, función y transducción de señal}

El receptor del factor de crecimiento epidérmico (EGFR), también conocido como HER1 o erbB1 es una glicoproteína ubicua que atraviesa la membrana celular. Está compuesta por una parte extracelular (amino-terminal) de unión al ligando, una región transmembrana hidrofóbica, y una parte citoplásmica que contiene el dominio tirosina quinasa y la región carboxi-terminal con residuos de tirosina críticos y motivos reguladores del receptor. La superficie celular es el lugar donde se producen las interacciones iniciales entre ligando-receptor y receptor-receptor. La unión de un conjunto especifico de ligandos (EGF, TGF $\alpha$, anfiregulina, betacelulina o epiregulina) al dominio extracelular activa la función catalítica citoplasmática promoviendo la dimerización del EGFR y la autofosforilación del receptor en residuos de tirosina. ${ }^{12}$ Estas tirosinas fosforiladas sirven como sitios de acoplamiento para un número de moléculas adaptadoras y transductoras de señales que inician múltiples rutas de señalización, resultando en una proliferación celular, diferenciación, migración, adhesión, protección contra apoptosis y transformación entre otros eventos. Las rutas de transducción de señales citoplásmicas que son activadas por el EGFR activo incluyen PLC-gamma-1, Ras-Raf-MEK-MAPKs, fosfatidilinoistol-3 quinasa (PI3K) y Akt, Src, (SAPKs, stress-activated protein kinases), PAK-JNKKJNK, y los transductores de señal y activadores de la transcripción (STATs). ${ }^{13}$ La mayor ruta de señalización de la familia ErbB es vía la ruta Ras-Raf-Map-quinasa. La activación de Ras inicia una cascada de fosforilaciones en múltiples pasos que conduce a la activación de MAPKs, ERK1 y ERK2 siendo estos reguladores de la trans- overexpression in epithelial cells leads to a reduction in apoptosis. This effect has been attributed, at least in part, to an increase in the levels of the anti-apoptotic protein BCl-2. COX2 overexpression may possibly prolong the survival of abnormal cells, thus favoring the sequential accumulation of genetic changes that increase the risk of carcinogenesis.

\section{Inflammation}

Chronic inflammation is a recognized risk factor in epithelial carcinogenesis. Cytokine-mediated COX-2 overexpression contributes to the increase in $P G$ synthesis in inflamed tissues, providing an explanation of the cause-effect relation between chronic inflammation and carcinogenesis by means of COX-2 overexpression.

\section{Angiogenesis}

Any significant increase in tumor mass must be preceded by an increase in vascular development to channel nutrients and oxygen to the tumor. It has been found recentIy that COX-2 levels correlate with VEGF expression and tumor vascularization in SCC.10

\section{Cell mobility and adherence}

The invasive capacity fostered by COX-2 is mediated by CD44, a cell surface receptor for hyaluronate. COX-2 overexpression enhances cellular invasive capacity and also increases CD44 expression. The biochemical changes associated with these tumor cell dynamics include increased expression and alteration of metalloprotease- 2 and diminished expression of E-cadherin.

\section{Epidermal growth factor receptor (EGFR)}

The EGF receptor was the first receptor to be identified in a family of receptors known as ErbB receptors. This family consists of the following related receptors: EGFR (ErbB1/EGFR/HER1), ErbB2 (HER2/neu), Erb3 (HER3), and ErbB4 (HER4). Under physiologic conditions, a variety of ligands of the EGFR family induce the formation of homodimer or heterodimer complexes between the four types of ErbB receptor. These complexes maintain signal diversification and amplification. ${ }^{11}$ In tumor cells these receptors can be activated by additional mechanisms and receptor overexpression in tumors can lead to dimerization of the independent ligand receptor. In some tumors, mutant forms of EGFR, which arise from genetic changes, reduce the constitutive expression of the dependent ligand receptor. These phenomena indicate that tumor cells have other mechanisms of EGFR activation in addition to receptor overexpression, mutations, and production of the autocrine ligand.

Structure, function, and signal transduction

Epidermal growth factor receptor (EGFR), also known as HER1 or erbB1, is a ubiquitous glycoprotein that cross- 
cripción de moléculas relacionadas con la proliferación celular, supervivencia y transformación. Otra ruta importante en la señalización de EGFR es la fosfatidilinositol 3-quinasa (PI3K) y la proteína serina/treonina quinasa Akt. ${ }^{14}$ Akt transduce señales que desencadenan una cadena de respuestas desde proliferación y crecimiento celular hasta supervivencia y motilidad. ${ }^{14}$ Otra ruta de señalización es la vía de la proteína quinasa activada bajo condiciones de estrés, participando la proteína quinasa C y Jak / Start. La activación de estas rutas se traduce en el núcleo en diferentes programas transcripcionales que median una variedad de respuestas celulares, incluyendo división celular, supervivencia (o muerte), movilidad, invasión, adhesión y reparación celular.

\section{Expresión basal de EGF-R y TGF- $\alpha$ en lesiones premalignas}

Los niveles de expresión de TGF- $\alpha$ y EGFR son mayores en leucoplasia que en mucosa normal adyacente. Los valores de expresión de TGF- $\alpha$ en mucosa normal adyacente hacia leucoplasia displásica son superiores en promedio a los detectados en mucosa oral de voluntarios sin leucoplasia (Fig. 3). En contraste y determinado mediante immunohistoquímica, en pacientes con CCS la expresión de TGF- $\alpha$ y EGFR está significativamente elevada en CCS y en la mucosa normal adyacente en comparación con mucosa oral de pacientes sin CCS. Los mecanismos por los cuales aumenta la expresión de TGF- $\alpha$ y EGFR en leucoplasia y CCS no se han determinado, pero éstos pueden incluir alteraciones en controles genéticos, en líneas celulares de CCS, el incremento de los niveles en mRNA de TGF- $\alpha$ y EGFR induce inicialmente en un incremento en la tasa de transcripción génica y no un incremento en el número de copias del gen ni alteraciones de la estabilidad del mensajero.

EGFR en cáncer de cabeza y cuello

La evidencia de que TGF $\alpha$ y EGFR participan en la carcinogénesis procede de estudios de transfección y de análisis de RNA y proteínas en experimentos con líneas celulares de tumores humanos incluyendo CCS. En humanos se ha observado que los niveles de TGF- $\alpha$ y EGFR en CCS y en mucosa normal adyacente están elevados. El receptor para el factor de crecimiento epidérmico (EGFR) está anormalmente activado en tumores epiteliales; las células de casi todas estas neoplasias expresan altos niveles de EGFR, una característica asociada con un peor pronóstico clínico. En los tumores analizados se encuentran niveles detectables de EGFR, aunque con marcadas diferencias entre los pacientes. Algunos investigadores no han encontrado diferencias significativas en la expresión de EGFR, ni entre las diferentes localizaciones anatómicas exploradas ni en los diferentes estados de diferenciación tumoral. Tampoco se han encontrado diferencias significativas en la distribución de los niveles de EGFR entre los tumores T1-2 y T3-4. Por el contrario, se ha observado una diferencia significativa en la distribución de los niveles de EGFR entre los estadios tumorales I y II frente a III y IV.

Basados en este valor umbral, la sobreexpresión de EGFR se ha asociado con una tasa libre de recidiva y una tasa de supervivencia global más baja con respecto a pacientes que muestran menores niveles de EGFR. Los análisis de la supervivencia, mediante modo univariante, muestran que el EGFR y el estadio tumoral son variables significativas, siendo el estadio tumoral la variable que asocia la mayor significación. Para la supervivencia libre de recidiva, el es the cell membrane. It is made up of an extracellular ligand-binding part (amino-terminal), a hydrophobic transmembrane region, and a cytoplasmic part containing the tyrosine kinase domain and the carboxy-terminal region, which has critical tyrosine residues and receptor regulator motifs. The cell surface is where the initial ligand-receptor and receptor-receptor interactions occur. The binding of a specific set of ligands (EGF, TGF- $\alpha$, amphiregulin, betacellulin, or epiregulin) to the extracellular domain activates the cytoplasmic catalytic function, promoting EGFR dimerization and autophosphorylation of the receptor at tyrosine residues. ${ }^{12}$ These phosphorylated tyrosines serve as binding sites for a number of adaptor and signal transducer molecules that initiate a number of signaling pathways that result in cellular proliferation, differentiation, migration, adhesion, protection against apoptosis, and transformation, among other events. The cytoplasmic signal transduction pathways activated by active EGFR include PLC-gamma-1, Ras-Raf-MEK-MAPKs, phosphatidylinositol3 kinase (PI3K), Akt, Src (SAPKs, stress-activated protein kinases), PAK-JNKK-JNK, and signal transducers and transcription activators (STATS). ${ }^{13}$ The major signaling pathway of the ErbB family is via the Ras-Raf-Map-kinase pathway. Ras activation initiates a cascade of phosphorylations in multiple steps that lead to the activation of MAPKS, ERK1, and ERK2, which are regulators of the transcription of molecules related to cellular proliferation, survival, and transformation. Another important EGFR signaling pathway is phosphatidylinositol-3 kinase (PI3K) and the serine/threonine kinase Akt protein. ${ }^{14}$ Akt transduces signals that trigger a chain of responses from proliferation and cell growth to survival and motility. ${ }^{14}$ Another signaling pathway is the protein kinase pathway activated under conditions of stress, in which protein kinase $\mathrm{C}$ and Jak/Start participate. The activation of these pathways is translated in the nucleus into different transcriptional programs that mediate a variety of cellular responses, including cell division, survival (or death), mobility, invasion, adhesion, and repair.

Baseline expression of EGF-R and TGF- $\alpha$ in premalignant lesions

The levels of TGF- $\alpha$ and EGFR expression are higher in leukoplakia than in adjacent normal mucosa. TGF- $\alpha$ expression levels in the normal mucosa adjacent to dysplastic leukoplakia are higher on average than the levels detected in the oral mucosa of volunteers without leukoplakia (Fig. 3). In contrast, immunohistochemical study shows that the expression of TGF- $\alpha$ and EGFR is significantly elevated in patients with SCC and in the adjacent normal mucosa but not in the oral mucosa of patients without SCC. The mechanisms by which TGF- $\alpha$ and EGFR expression increases in leukoplakia and SCC have not been determined, but they may include alterations in genetic controls, SCC cell lines, and the mechanisms by which increased TGF- $\alpha$ and EGFR mRNA levels initially induce an increment in the rate of gene transcription 
EGFR ha sido el único parámetro significativo. En otros estudios, la frecuencia de tumores CCS con altos niveles de EGFR fue generalmente más baja que los datos publicados previamente ${ }^{15,16} \mathrm{y}$ también, la correlación de tumores bien o moderadamente diferenciados y los tumores pequeños es contradictoria con estudios previos. En este sentido, la expresión del EGFR se correlaciona con CCS bien diferenciado y moderadamente diferenciado; el tamaño del tumor se correlaciona con un incremento en los valores de expresión, siendo más frecuente en tumores T1-2. Por el contrario, no se encuentra correlación entre el tamaño del tumor y el grado de diferenciación histológica. Una posible explicación a los resultados contradictorios obtenidos en los diferentes estudios publicados es la falta de consenso para la visualización del receptor y definir los niveles de los puntos de corte; además, la intensidad de la tinción puede ser dependiente de la fijación del tejido. Otras explicaciones posibles para las diferencias observadas podrían estar relacionadas con diferencias en la expresión de EGFR en varios puntos del tumor y la asociación entre la presencia de la infección del virus del papiloma humano y la expresión del receptor. ${ }^{17}$ Otros trabajos han mostrado que, comparando los niveles en mucosa normal de pacientes sin cáncer, el 80-90\% de los CCS sobreexpresa EGFR y su ligando, TGF- $\alpha$, con un incremento medio de 69 y 5 veces, respectivamente. El estudio posterior realizado por el mismo grupo de investigadores ha revelado que en pacientes con CCS, el mRNA y la proteína de EGFR están también sobreexpresados en lesiones displásicas e incluso en la mucosa normal adyacente. Todas estas observaciones indican que la sobreexpresión de EGFR es un evento temprano en el desarrollo de CCS.

\section{Expresión de otros miembros ErbB}

La expresión de Her2 se detecta en un $20 \%$ de los casos y su sobreexpresión parece estar asociada con un alto riesgo de metástasis ganglionar y peor supervivencia en pacientes con carcinomas orales. Aproximadamente la mitad de los carcinomas de la cavidad oral expresaron Her3 y, al igual que Her2, su sobreexpresión se asocia con una mayor incidencia de diseminación ganglionar. ${ }^{18}$ La expresión de Her4 también se ha detectado en la mitad de los carcinomas de la cavidad oral. ${ }^{19}$

\section{Perspectivas clinicas y direcciónes terapéuticas}

\section{Agentes quimioprentivos}

La prevención utilizando fármacos, o quimioprevención, han sido estrategias evaluadas y constituyen a día de hoy una débil promesa para disminuir la morbilidad y mortalidad asociada con el cáncer. Se han evaluado diversos agentes como posibles terapias quimiopreventivas. Entre ellas cabe destacar vitaminas (A, E, C) y minerales (Selenio). En cuanto a la búsqueda de nuevas dianas moleculares, otros estudios han incluido los inhibidores de COX-2, e inhibidores de EGFR (Fig. 4) como posibles agentes terapéuticos.

\section{Dianas Moleculares}

Existen evidencias que demuestran que las prostaglandinas están implicadas en carcinogénesis, siendo la prostaglandina E2 respon- but not in the number of gene copies or alterations in messenger stability.

EGFR in cancer of the head and neck

The evidence that TGF- $\alpha$ and EGFR participate in carcinogenesis comes from studies of transfection and analysis of RNA and proteins in experiments with human tumor cell lines, including SCC. In humans, it has been observed that TCF- $\alpha$ and EGFR levels are elevated in SCC and in the adjacent normal mucosa. Epidermal growth factor receptor (ECFR) is abnormally activated in epithelial tumors; the cells of almost all these neoplasms express high EGFR levels, which is a characteristic associated with a less favorable clinical prognosis. Detectable levels of EGFR are found in the tumors analyzed, although with noticeable differences between patients. Some investigators have not found significant differences in EGFR expression between either different anatomic sites or different states of tumor differentiation. Significant differences have not been found in the distribution of EGFR levels between tumors T1-2 and T3-4. In contrast, a significant difference is observed in the distribution of EGFR levels between tumor stages I and II and tumor stages III and IV.

Based on this threshold value, EGFR overexpression has been associated with a lower recurrence-free rate and overall survival rate with respect to patients who exhibit lower EGFR levels. Univariate analysis of survival shows that EGFR and tumor stage are significant variables, tumor stage being the most significant variable associated. For recurrence-free survival, EGFR has been the only significant parameter. In other studies, the frequency of SCC tumors with high EGFR levels generally is lower than previously published data ${ }^{15,16}$ and the correlation of well or moderately differentiated tumors and small tumors does not coincide with previous studies. In this sense, EGFR expression correlates with well differentiated and moderately differentiated SCC; the size of the tumor correlates with an increase in EGFR expression, particularly in T1-2 tumors. In contrast, no correlation is found between tumor size and the degree of histologic differentiation. A possible explanation for the contradictory results obtained in different published studies is the lack of consensus on the visualization of the receptor and the definition of cutoff points. In addition, the intensity of staining may be dependent on tissue fixation parameters. Other possible explanations for the differences observed could be related to differences in EGFR expression in different points of the tumor and the association between the presence of human papilloma virus infection and expression of the receptor. ${ }^{17}$ Other studies have demonstrated that $80-90 \%$ of SCCs overexpress EGFR and its ligand, TGF- $\alpha$, compared to levels in the normal mucosa of patients without cancer, with mean increases of 69-fold and 5 -fold, respectively. A later study by the same group of investigators revealed that EGFR MRNA and protein also are overexpressed in patients with SCC in dysplastic lesions and even in the adjacent normal mucosa. These observations indicate that EGFR overexpression is an early event in SCC development. 
sable de la activación de EGFR, con la consecuente estimulación de la proliferación celular (Fig. 5). En este sentido, COX-2 puede ser un determinante de la expresión de EGFR en lesiones epiteliales orales premalignas como también en CCS (Fig. 6), por lo que la inhibición de la ruta de COX-2 y/o EGFR proporcionaría una diana ideal para terapia molecular en lesiones premalignas de la cavidad oral. La implicación del EGFR en el carcinoma de células escamosas ha estimulado el uso clínico de varios agentes para bloquear la función de esta proteína. En concreto, ya se han demostrado con probada eficacia dos anticuerpos monoclonales, Cetuximab y Gefitinib como agentes terapéuticos para el carcinoma oral.

Gefitinib detiene la proliferación y el ciclo celular en fase G1 y reduce las metástasis ganglionar regional en ratones con carcinoma de células escamosas oral (CCSO). ${ }^{20}$ De igual modo, Cetuximab promueve la detención en fase $\mathrm{G} 1$ del ciclo celular en células cultivadas de CCSO. ${ }^{21}$ La exposición al Gefitinib también aumenta la radiosensibilidad de células de CCSO in vitro e in vivo. ${ }^{22}$ Recientemente se ha desarrollado un ensayo aleatorio del inhibidor EGFR EKB-569 sólo, Celecoxib (400 mg dos veces al día) sólo, la combinación de los dos fármacos o placebo en pacientes que presentaron leucoplasia oral displásica aneuploide. ${ }^{5}$

\section{Conclusiones}

Las lesiones premalignas orales se desarrollan a lo largo de superficies epiteliales del tracto aerodigestivo. Estas lesiones pueden abocar al desarrollo del CCS en la misma zona de la lesión. En este sentido, la carcinogénesis del tracto aerodigestivo implica una transición histológica en múltiples pasos desde epitelio normal hasta CCS. Este proceso implica una serie de cambios no sólo a nivel celular y molecular, sino también cambios en la expresión de genes que codifican para diferentes factores de crecimiento. Es por ello por lo que se está haciendo un gran esfuerzo por identificar nuevos marcadores de las lesiones premalignas de la mucosa del tracto aerodigestivo superior.

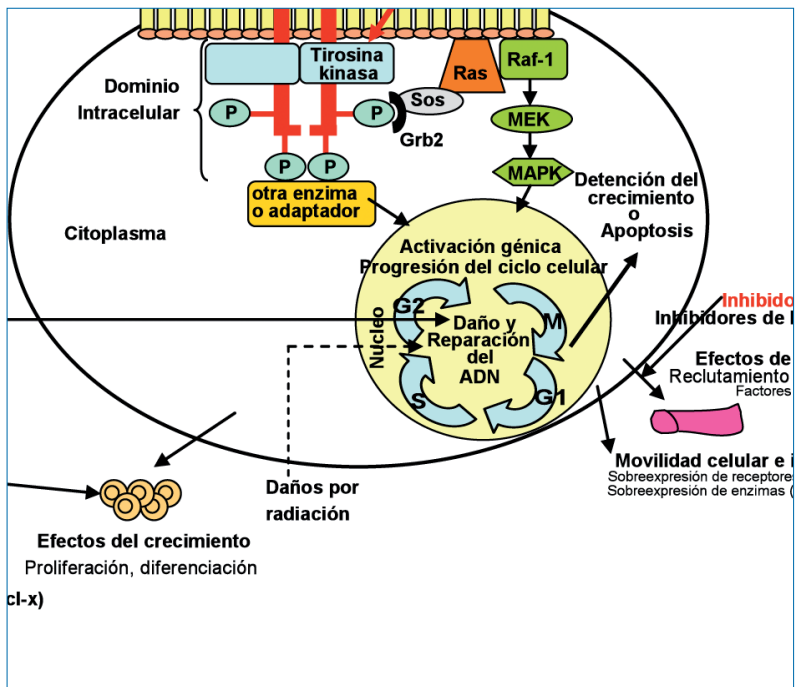

Figura 4. El bloqueo del EGFR provoca la inhibición de las rutas de señalización dentro de la célula tumoral provocando un descenso de la proliferación, angiogénesis e invasión, y un incremento en la apoptosis. TGF $\alpha$ (transforming growth factor alpha). Figure 4. EGFR blockade causes inhibition of the signaling pathways in the tumor cell, causing a reduction in proliferation, angiogenesis, and invasion and an increase in apoptosis. TGF- $\alpha$ (transforming growth factor alpha).

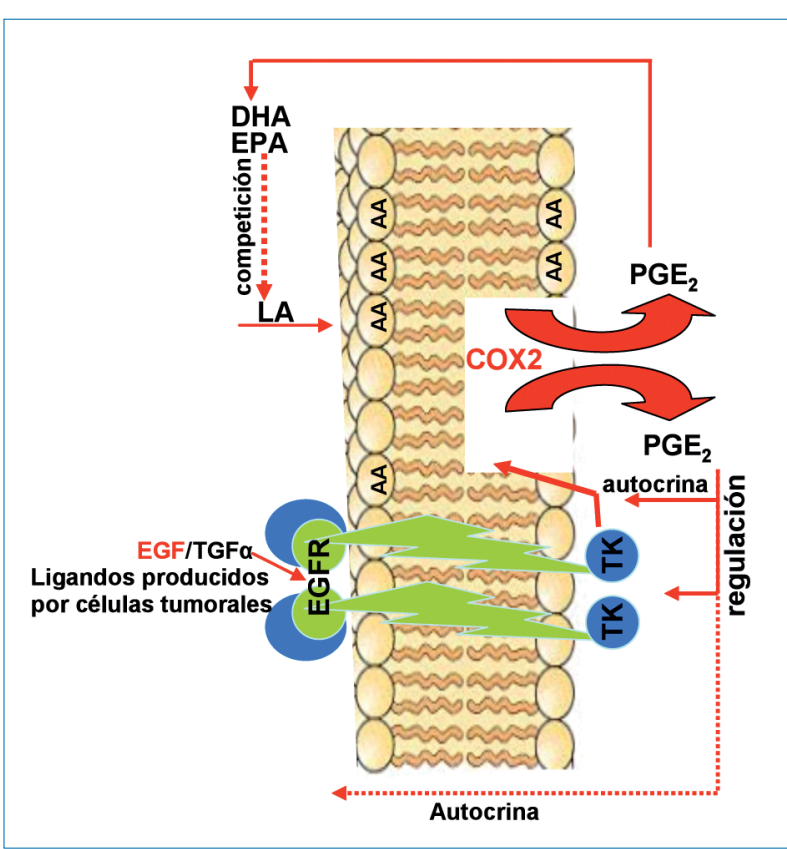

Figura 5. Interacción del factor de crecimiento epidérmico en la biosíntesis de eicosanoides. El ácido docosahexaenoico (DHA) y el ácido eicosapentaenoico (EPA) compiten con el ácido linoleico (LA) y su producto metabólico, el ácido araquidónico (AA). La movilización del ácido araquidónico implica a la fosfolipasa A2, una enzima que es estimulada por EGF.

Figure 5. Interaction of the epidermal growth factor in the biosynthesis of eicosanoids. Docosahexaenoic acid (DHA) and eicosapentaenoic acid (EPA) compete with linoleic acid (LA) and its metabolic product, arachidonic acid (AA). The mobilization of arachidonic acid involves phospholipase A2, an enzyme that is stimulated by EGF.
Expression of other ErbB markers

Her2 expression is detected in 20\% of cases and its overexpression seems to be associated with a high risk of lymph node metastasis and lower survival in patients with oral carcinoma. Approximately half of the carcinomas of the oral cavity express Her3 and Her3 overexpression, like Her2 overexpression, is associated with a higher incidence of lymph node dissemination. ${ }^{18}$ Her 4 expression also has been detected in half of the carcinomas of the oral cavity. ${ }^{19}$

\section{Clinical perspectives and therapeutic trends}

Chemopreventive agents

Prevention using drugs, or chemoprevention, is a strategy that has been evaluated and found to hold some promise of reducing the morbidity and mortality associated with cancer. Diverse agents have been evaluated as possible chemopreventive therapies. Among them are vitamins ( $A, E$, and $C$ ) and minerals (selenium). As for the search for new molecular targets, other studies have included COX-2 inhibitors and EGFR inhibitors (Fig. 4) as possible therapeutic agents.

\section{Molecular targets}

Evidence exists that demonstrates that prostaglandins are involved in carcinogenesis; prostaglandin E2 is responsible for the activation of EGFR, which leads to stimulation of cell proliferation (Fig. 5). In this sense, COX-2 can be a determi- 

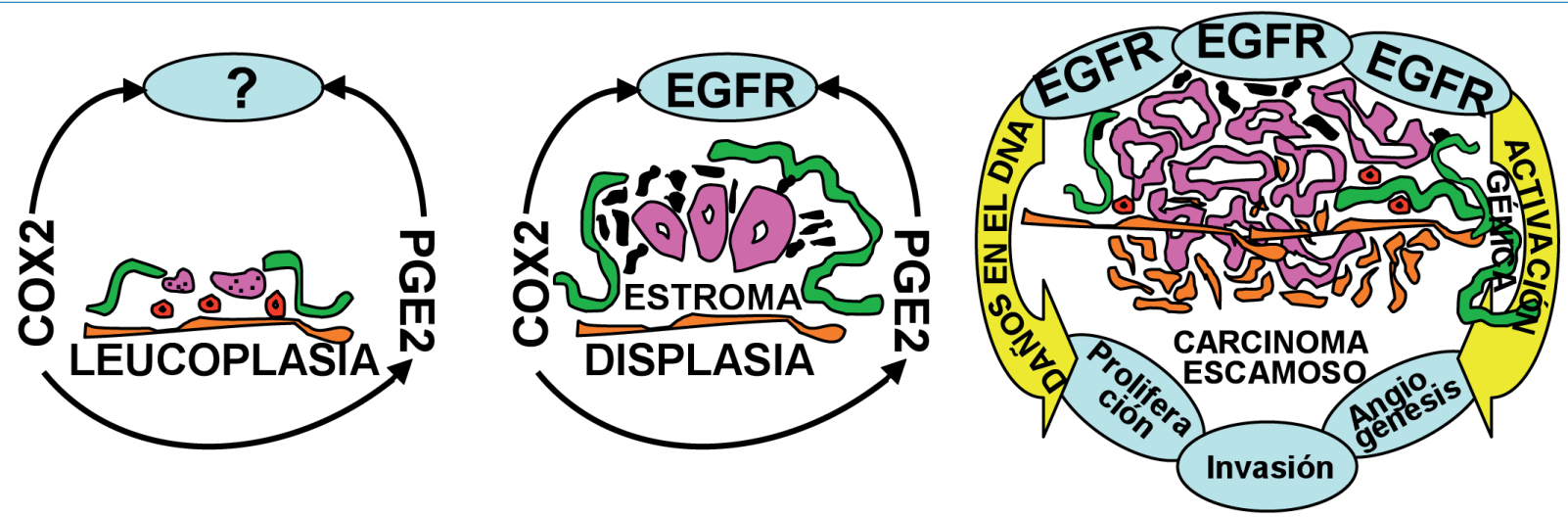

Figura 6. Dibujo esquemático de una carcinogénesis en donde se muestra la transición desde epitelio preneoplásico oral hasta carcinoma de células escamosas. Cuando la leucoplasia naciente se expande, COX-2 se activa en el epitelio que se está transformando (probablemente rodeando al estroma) y desempeña un papel esencial en el crecimiento posterior. El incremento de los niveles de COX-2 en la lesión premaligna desencadena la sobreexpresión del EGFR, un evento que ocurre pronto en el desarrollo de la carcinogénesis epitelial oral.

Figure 6. Diagram of carcinogenesis showing the transition from oral preneoplastic epithelium to squamous-cell carcinoma. When incipient leukoplakia expands, COX-2 is activated in the epithelium that is being transformed (probably surrounding the stroma) and plays an essential role in the later growth. Increased COX-2 levels in the premalignant lesion trigger EGFR overexpression, an event that occurs early in the development of oral epithelial carcinogenesis.

Entre los diferentes marcadores que se han propuesto hasta la actualidad, la ciclooxigenasa-2 (COX-2) y el receptor del factor de crecimiento epidérmico (EGFR) parecen ser los más prometedores. Las evidencias reales de que COX-2 y EGFR están sobreexpresados en CCS de cabeza y cuello, arrastran el pensamiento hacia la conveniencia de explorar si ambos marcadores pueden ser utilizados como SEBs en lesiones premalignas (tipo leucoplasias) de la mucosa oral.

\section{Agradecimientos}

A. Carro Ramos por su ayuda técnica. S. Díaz Prado es beneficiaria de un contrato post-doctoral de investigación dentro del Programa Isidro Parga Pondal por la Xunta de Galicia (La Coruña, Galicia, España).

\section{Bibliografía}

1. Mao L, Hong WK, Papadimitrakopoulou VA. Focus on head and neck cancer. Cancer Cell 2004;5:311-6.

2. Hasegawa M, Nelson HH, Peters E, Ringstrom E, Posner M, Kelsey KT. Patterns of gene promoter methylation in squamous cell cancer of the head and neck. Oncogene 2002;21:4231-6.

3. Herman JG, Baylin SB. Gene silencing in cancer in association with promoter hypermethylation. N Engl J Med 2003;349:2042-54.

4. Youssef EM, Lotan D, Issa JP, Wakasa K, Fan YH, Mao L, y cols. Hypermethylation of the retinoic acid receptor-beta(2) gene in head and neck carcinogenesis. Clin Cancer Res 2004;10:1733-42.

5. Dannenberg AJ, Lippman SM, Mann JR, Subbaramaiah K, Dubois RN. Cyclooxygenase-2 and epidermal growth factor receptor: pharmacologic targets for cheomoprevention. J Clin Oncol 2005;23:254-66.

6. Lippman SM, Sudbo J, Hong WK. Oral cancer prevention and the evolution of molecular targeted drug development. J Clin Oncol 2005;23:346-56. nant of EGFR expression in oral premalignant epithelial lesions as well as in SCC (Fig. 6), which is why the inhibition of the COX-2 and/or EGFR pathway would be an ideal target for molecular therapy of premalignant lesions of the oral cavity. The implication of EGFR in squamous cell carcinoma has inspired the clinical use of several agents to block the function of this protein. In particular, the effectiveness of two monoclonal antibodies, cetuximab and gefitinib, as therapeutic agents for oral carcinoma has already been demonstrated.

Gefitinib arrests cell proliferation and the cell cycle in the G1 phase and reduces regional lymph node metastases in mice with oral squamous-cell carcinoma (OSCC). ${ }^{20}$ Similarly, cetuximab promotes the detention of OSCC cell cultures in the $G 1$ phase of the cell cycle. ${ }^{21}$ Exposure to gefitinib also enhances the radiosensitivity of OSCC cells in vitro and in vivo. ${ }^{22}$ Recently, a randomized clinical trial was conducted of the EGFR inhibitor EKB-569 alone, celecoxib $(400 \mathrm{mg}$ twice a day) alone, the combination of the two drugs, or placebo in patients who presented oral aneuploid dysplastic leukoplakia. ${ }^{5}$

\section{Conclusions}

Oral premalignant lesions develop on the epithelial surfaces of the aerodigestive tract. These lesions can lead to the development of SCC in the same area of the lesion. In this sense, field cancerization of the aerodigestive tract involves a multiple-step histologic transition from normal epithelium to SCC. This process involves a series of changes not only at the cellular and molecular level, but also changes in the expression of genes that encode different growth factors. For that reason concerted efforts are being made to identify new 
7. Wiese FW, Thompson PA \& Kadlubar FF. Carcinogen substrate specificity of human COX-1 and COX-2. Carcinogenesis 2001;21:5-10.

8. Williams CS, Tsujii M, Reese J, Dey SK, DuBois RN. Host cyclooxygenase-2 modulates carcinoma growth. / Clin Invest 2000;105:1589-94.

9. Chan G, Boyle JO, Yang EK, Zhang F, Sacks PG, Shah JP, et al. Cyclooxygenase2 expression is up-regulated in squamous cell carcinoma of the head and neck. Cancer Res 1999;59:991-4.

10. Gallo O, Franchi A, Magnelli L, Sardi I, Vannacci A, Boddi V, y cols. Cyclooxygenase-2 pathway correlates with VEGF expression in head and neck cancer. Implications for tumor angiogenesis and metastasis. Neoplasia 2001;3:53-61.

11. Schlessinger J. Cell signaling by receptor tyrosine kinase. Cell 2000;103:211- 25.

12. Yarden $\mathrm{Y}$, Sliwkowski M. Untangling the ErbB signaling network. Nat Rev Mol Cell Biol 2001;2:127-37.

13. Olayioye MA, Neve RM, Lane HA, Hynes NE. The ErbB signaling network: Receptor heterodimerization in development and cancer. EMBO J 2000;19:3159-67.

14. Vivanco I, Sawyers CL. The phosphatidylinositol 3-Kinase-Akt pathway in human cancer. Nat Rev Cancer 2002;2:489-501.

15. Gupta AK, McKenna WG, Weber CN, Feldman MD, Goldsmith JD, Mick R, y cols. Local recurrence in head and neck cancer: Relationship to radiation resistance and signal transduction. Clin Cancer Res 2002;8:885-92.

16. Bei R, Pompa G, Vitolo D, Moriconi E, Ciocci L, Quaranta M, et al. Co-localization of multiple ErbB receptors in stratified epithelium of oral squamous cell carcinoma. J Pathol 2001;195:343-8.

17. Almadori G, Cadoni G, Cattani P, Galli J, Bussu F, Fernandina G, et al. Human papillomavirus infection and epidermal growth factor receptor expression in primary laryngeal squamous cell carcinoma. Clin Cancer Res 2001;7:3988-93.

18. Xia W, Lau YK, Zhang HZ, Xiao FY, Johnston DA, Liu AR, y cols. Combination of EGFR, HER-2/neu and HER-3 is a stronger predictor for the outcome of oral squamous cell carcinoma than any individual family members. Clin Cancer Res 1999; 5:4164-74.

19. Ang KK, Andratschke NH, \& Milas L. Epidermal growth factor receptor and response of head-and-neck carcinoma to therapy. Int J Radiat Oncol Biol Phys 2004;58:959-65.

20. Shintani S, Li C, Mihara M, Nakashiro K, Hamakawa H. Gefitinib (Iressa), an epidermal growth factor receptor tyrosine kinase inhibitor, mediates the inhibition of lymph node metastasis in oral cancer cells. Cancer Lett 2003;201:149-55.

21. Kiyota A, Shintani S, Mihara M, Nakahara Y, Ueyama Y, Matsumura T, y cols. Anti-epidermal growth factor receptor monoclonal antibody 225 upregulated p27 (KIP1) and p15 (INK 4B) and induces G1 arrest in oral squamous carcinoma cell lines. Oncology 2002;63:92-8.

22. Harari PM, Huang SM. Head and neck cancer as a clinical model for molecular targeting of therapy: combining EGFR blockade with radiation. Int I Radiat Oncol Biol Phys 2001;49:427-33. markers of premalignant lesions of the mucosa of the upper aerodigestive tract. Among the markers that have been proposed so far, cyclooxygenase-2 (COX-2) and epidermal growth factor receptor (EGFR) appear to be the most promising. Real evidence that COX-2 and EGFR are overexpressed in SCC of the head and neck suggests that it would be useful to study whether these two markers can be used as SEBS in premalignant lesions (leukoplakia type) of the oral mucosa.

\section{Acknowledgments}

We thank A. Carro Ramos for technical assistance. S. Diaz Prado received a postdoctoral research contract from the Isidro Parga Pondal Program of the Regional Executive of Galicia (Corunna, Galicia, Spain). 